\title{
Improving the Quality of Life of Patients with Chronic Kidney Disease Undergoing Hemodialysis through Family Supportive Therapy
}

\author{
$1^{\text {st }}$ Virgianti Nur Faridah \\ Nursing Doctoral Student \\ Faculty of Nursing \\ Universitas Airlangga \\ Surabaya, Indonesia \\ virgianti.nur.faridah-2019@ fkp.unair.ic.id \\ $4^{\text {th }}$ Siti Sholikhah \\ Lecturer of Health Science Faculty \\ Universitas Muhammadiyah Lamongan \\ Lamongan, Indonesia
}

\author{
$2^{\text {nd }}$ Nursalam \\ Profesor Faculty of Nursing \\ Universitas Airlangga Surabaya \\ Indonesia
}

\author{
$5^{\text {th }}$ Fifit Sri Rukmawati \\ Nursing Bachelor Student \\ Universitas Muhammadiyah Lamongan \\ Lamongan, Indonesia
}

\author{
$3^{\text {rd }}$ Arifal Aris \\ Lecturer of Health Science Faculty \\ Universitas Muhammadiyah Lamongan \\ Lamongan, Indonesia
}

\begin{abstract}
Chronic kidney disease is a disorder of kidney function that is progressive and irreversible. Patients with dialysis therapy may not improve survival and might damage the quality of life. The purpose of this study was to determine the effect of family-supportive therapy on the quality of life of patients with chronic kidney disease undergoing hemodialysis. The research design used preexperimental One Group Pretest-Posttest Design. The data were obtained from 88 respondents of chronic kidney disease who undergoing hemodialysis at Soegiri general hospital of Lamongan in March 2018 by using quality of life questionnaire WHOQOL-BREF. The data analysis used the Wilcoxon test with a significance level of $P$ less than 0.05. The results showed that before being given family supportive therapy, the quality of life was moderate, and after treatment, the quality of life was high. Based on the Wilcoxon test results, it was obtained the value of $Z=\mathbf{- 5 . 1 9 6}$ with a value of $p=0.000$. This shows that there is an effect of supportive therapy on the quality of life of patients with chronic kidney disease. Nurses can provide support for the patient's independence in modifying lifestyles by involving the family's active role in improving the quality of life of patients.
\end{abstract}

Keywords-Improving, Quality Life, Patients, Chronic Kidney, Hemodialysis

\section{INTRODUCTION}

One of the major health problems in the world that have a great influence on the quality of life of patients and their families is chronic kidney disease[1]. Quality of life is a matter of concern because it is an indicator of general well-being[2]. Quality of life is now a determining factor in the short and long term mortality rates of several pathological conditions[3], such as CKD [4].

Hemodialysis therapy for patients with chronic kidney disease is an effort to prevent death or prolong life.
However, hemodialysis cannot cure or restore kidney disease so the patient's quality of life decreases. Two study findings show that about half of patients hemodialysis does not changed in the quality of life, while a quarter reported increase and the rest has experienced a fall in the quality of life[5], [6].

Hemodialysis therapy has been undertaken by more than 2 million people worldwide with the majority never receiving a kidney transplant[7]. Indonesia is a country with a high number of CKD patients, the Indonesian Renal Registry reports that there are 52,835 people with active hemodialysis in Indonesia. This number will continue to increase by around $10 \%$ every year[8]. While based on data from Riskesdas in 2018, the prevalence of chronic kidney disease in Indonesia is $0.38 \%$ of the total diagnosis and the proportion of hemodialysis is $19.33 \%$ of the diagnosis[9].

Patients with chronic kidney disease cannot be cured so that the quality of life of patients decreases. The decrease of quality of life in chronic kidney disease patients undergoing hemodialysis therapy will cause prolonged complications, decreased productivity and create negative mood. Patients' perceptions of their deteriorating quality of life can aggravate their condition[10]. The quality of life of patients with Chronic Kidney Disease undergoing hemodialysis attract enough attention for health professionals because the quality of life issues are very important in providing comprehensive nursing services to patients, with the hope that patients can undergo hemodialysis and be able to survive even with the help of dialysis machines[11].

Supportive therapy is a choice of therapy that is intended to improve the ability of the family as a support system. The support group is a therapy that is organized to 
help members exchange experiences about certain problems to improve their coping. Supportive groups are intended to reduce family burdens and improve family coping and increase social support. The purpose of establishing a support group is to provide support. The goals and expectations of the group are positive group experiences. An important goal is the immediate resolution of the problem and provides motivation and change in individual behaviour[12].

Supportive family therapy is still recommended for families who have family members who are sick. This proves the importance of family-supportive therapy to arouse and support clients and families. So, the client feels cared for by the family. The family is also knowledgeable about how to give good and correct care for the family member[13]. The purpose of this study was to determine the effect of family-supportive therapy on the quality of life of patients with chronic kidney disease undergoing hemodialysis.

\section{METHODS}

The research design used pre-experimental One Group Pretest-Posttest Design. The data were obtained from 88 respondents with chronic kidney disease undergoing hemodialysis at the Soegiri general hospital of Lamongan in March 2018 by using quality of life questionnaire WHOQOL-BREF. Data analysis using the Wilcoxon test with significance level $\mathrm{P}<0.05$.

\section{RESULT}

TABLE 1. RESPONDENTS' CHARACTERISTICS

\begin{tabular}{|c|c|c|}
\hline Respondents' Characteristics & Frequency & Percentage (\%) \\
\hline \multicolumn{3}{|c|}{ Age } \\
\hline $20-30$ years old & 6 & 6.8 \\
\hline $31-40$ years old & 10 & 11.4 \\
\hline $41-50$ years old & 35 & 39.8 \\
\hline $51-60$ years old & 37 & 42.0 \\
\hline \multicolumn{3}{|c|}{ Gender } \\
\hline Male & 45 & 51.1 \\
\hline Female & 43 & 48.9 \\
\hline \multicolumn{3}{|c|}{ Educational Degree } \\
\hline Didn't go to school & 3 & 3.4 \\
\hline Primary School & 28 & 31.8 \\
\hline Junior High School & 19 & 21.6 \\
\hline Senior High School & 22 & 25.0 \\
\hline Bachelor & 16 & 18.2 \\
\hline \multicolumn{3}{|c|}{ Occupational Distribution } \\
\hline No Job & 26 & 29.5 \\
\hline Entrepreneur & 21 & 23.9 \\
\hline Government employees & 14 & 15.9 \\
\hline Farmer & 27 & 30.7 \\
\hline
\end{tabular}

TABLE 2. THE QUALITY OF LIFE LEVEL OF PATIENTS WITH CKD UNDERGOING HEMODIALYSIS BEFORE FAMILY SUPPORTIVE THERAPY

\begin{tabular}{|c|c|c|}
\hline QoL & Frequency & $\begin{array}{c}\text { Percentage } \\
(\boldsymbol{\%})\end{array}$ \\
\hline $\begin{array}{c}\text { Very } \\
\text { Low }\end{array}$ & 6 & 6,8 \\
\hline Low & 32 & 36,4 \\
\hline Moderate & 50 & 56,8 \\
\hline High & 0 & 0 \\
\hline $\begin{array}{c}\text { Very } \\
\text { High }\end{array}$ & 0 & 0 \\
\hline Total & 88 & 100 \\
\hline
\end{tabular}

TABLE 3. THE QUALITY OF LIFE LEVEL OF PATIENTS WITH CKD UNDERGOING HEMODIALYSIS AFTER FAMILY SUPPORTIVE THERAPY

\begin{tabular}{|c|c|c|}
\hline QoL & Frequency & $\begin{array}{c}\text { Percentage } \\
(\%)\end{array}$ \\
\hline $\begin{array}{c}\text { Very } \\
\text { Low }\end{array}$ & 0 & 0 \\
\hline Low & 9 & 10 \\
\hline Moderate & 35 & 40 \\
\hline High & 44 & 50 \\
\hline $\begin{array}{c}\text { Very } \\
\text { High }\end{array}$ & 0 & 0 \\
\hline Total & 88 & 100 \\
\hline \multicolumn{2}{|c|}{$\mathrm{Z}=-5,196^{\text {a }}$ dan $\mathrm{p}=0,000$} \\
\hline
\end{tabular}

\section{DISCUSSION}

\section{A. Respondents' Characteristics}

The prevalence of chronic kidney disease (CKD) and end-stage kidney disease (ESRD) increases by age[14]. Age affects one's perspective on the future, life and decision making. Elderly patients tend to leave decisions to their immediate family. This will affect how the patient's efforts to improve physical complaints by utilizing health services[15]. Gender is almost balanced between men and women with a percentage of $51.1 \%$ and $48.9 \%$. This shows that CKD can occur in both men and women[15]. There were no significant associations between dialysis modality and age, gender or ethnicity[16].

The most recent education in CKD patients was classified as low, namely elementary school (31.8\%). The level of education plays an important role in determining health status, management abilities, and disease prevention. Management of chronic diseases requires good knowledge and abilities so that they can improve their quality of life. Dialysis patients often report feeling less independent, unable to participate in activities they enjoy and have an overall decline in functional status and quality of life[17].

Most respondents (30.7\%) are farmers, but quite a lot $(29.5 \%)$ of them do not work. Someone's work indirectly can lead to an unhealthy lifestyle. Some factors that trigger kidney problems include stress, fatigue, consumption of supplement drinks, consumption of herbs and dangerous drugs for a long time, foods that contain preservatives, and lack of drinking water.

B. The Level of quality of life of patients $C K D$

undergoing hemodialysis before Family Supportive

Therapy

Based on table II, before being given family supportive therapy the quality of life was moderate $(56,7 \%)$. Reference [18] showed that the quality of life of patients for the physical and psychological domains included in the category of moderate quality of life, while the environmental and social domains included in the category of good quality of life. Patients with chronic kidney disease will have a dependency on hemodialysis therapy routinely to maintain the quality of life[10].

World Health Organization (WHO) defines the quality of life as the individual perception about their position in 
life in the context of culture and value system and related to the purpose, hope, standard and concern in their live[19]. CKD patients undergoing dialysis are more sensitive to infections because of general frailty and depression in the immunologic system and signs and symptoms of infection can be prevented by drug therapy[11]. Poor general health conditions are often associated with poor quality of life[20]. CKD can affect the quality of life of patients which can be observed in the social, environmental, physical, and psychological domains. The severity of the symptoms and the duration of the disease make it important to evaluate the patient's quality of life[18]. QoL in CKD is an important thing that needs to be managed. Prolong survival of patients CKD is an important intervention. It has equal importance given toward maintaining of QOL[11].

\section{The Level of quality of life of patients $C K D$ undergoing hemodialysis after Family Supportive Therapy}

Based on table III, after being given family supportive therapy, the quality of life was high $(50 \%)$. Based on the Wilcoxon test results obtained the value of $\mathrm{Z}=-5,196$ with a value of $p=0,000$. This shows that there is an effect of supportive therapy on the quality of life of patients with chronic kidney disease.

Family members are often involved in the treatment of chronic kidney failure patients as care partners. The family of hemodialysis patients is an important agent in disease management and improving the quality of life of patients. More than $90 \%$ of patient care is carried out by families. The family helps patients at various stages of the disease, including physical, psychological, and mental care that is not limited to an advanced stage of the disease[21]. Hemodialysis is a burdensome and complex therapy that requires a lot of support from the family[22]. As care partners, family members are involved in many important activities, some of which include drug administration, supervise medication adherence, assist in daily care activities, scheduling and providing transportation when attending medical appointments, monitor patient health, advocating for patients and offer emotional support[23].

The role of the family is beneficial for patients and health care providers. For patients, family member involvement is associated with improved behavior and self-management care and adherence to therapy, improved quality of life, reduced risk of death, reduced anxiety and depressive symptoms, and reduced chances of hospital admission. For healthcare providers, family members are invaluable partners in the task of caring for patients with chronic kidney failure[24]. Chronic kidney failure requires immediate and ongoing treatment at home after undergoing hemodialysis therapy in a hospital[25]. Efforts to prepare families for the care of hemodialysis patients include through more family-centered care, provision of appropriate education early on, and interventions that target readiness of care partners, communication that focuses on readiness between health care providers and patients' family members, and the establishment of dynamics relationship between family and patient[24]. To overcome this problem, it is necessary to form psychoeducational support groups that can empower families by providing the knowledge and emotional support needed for successful care[26].

The increase in the quality of life of patients with chronic kidney disease undergoing hemodialysis is influenced by several factors, one of which is the patient's understanding of the disease. Support from the family is one of the important roles in supporting behavioral change, increasing patient understanding of the disease, so that optimal health is achieved, adjusting psychological conditions and improving the quality of life of the illness, treatment can affect the functional capacity of patients with chronic kidney disease which is defined as quality of life[12]. Reference [12] showed an increase in cognitive, affective and psychomotor abilities in families in treating patients with chronic kidney failure after being given supportive therapy compared to given health education.

Family supportive therapy is a small community group, each member gets the opportunity to practice in a group so that they do the behavior according to the example and feel the emotions that accompany the behavior, each group member gives feedback to each other, praise and encouragement, the client feels the similarity of the client is aware that there are other patients experience problems similar to themselves thereby increasing self-disclosure and motivating to change[13].

Family support is the attitude, actions and family acceptance of patients who are sick. The family also functions as a member system and family members view that supportive patients are always ready to assist with assistance if needed[27]. Family support is in the form of verbal and non-verbal support, advice, tangible assistance or behaviour provided by patients who are familiar with the subject in their social environment or in the form of attendance and things that can provide emotional benefits or affect the behaviour of the recipient[12].

Based on the results above, it can be concluded that supportive therapy can improve the quality of life of patients with chronic kidney disease undergoing hemodialysis. Supportive therapy is a psychotherapy therapy that is shown to clients both individually and in groups. Supportive therapy is a form of group therapy that can be done in a variety of situations and conditions including on clients with the quality of life problems, supportive groups are a group of patients who plan, manage and respond directly to special issues and pressures. The initial goal of this group is to provide support and complete the hemodialysis experience of each patient.

\section{CONCLUSION AND RECOMMENDATION}

\section{A. Conclusion}

From the study, it can be concluded that most respondents have moderate quality of life before being given family supportive therapy, but after being given family supportive therapy the quality of life was high. 


\section{B. Recommendation}

Nurses can provide family supportive therapy for the patient's independence in modifying lifestyles by involving the family's active role in improving the quality of life of patients.

\section{ACKNOWLEDGMENT}

We wish to thank Universitas Muhammadiyah Lamongan for financial support and our team for administrative support. This study is part of the initial research for my dissertation. Furthermore, we are grateful to Prof. Nursalam, M.Nurs (Hons) for his advice on my research.

\section{REFERENCES}

1] M. H. Ghiasi, B., Sarokhani, D., Dehkordi, A. H., Sayehmiri, K., \& Heidari, "Quality of Life of patients with chronic kidney disease in Iran: Systematic Review and Meta-analysis.," Indian J. Palliat. Care, vol. 24, no. 1, pp. 104-111, 2018.

[2] T. Kendrick, M. Moore, S. Gilbody, R. Churchill, B. Stuart, and M. El-Gohary, "Routine use of patient reported outcome measures (PROMs) for improving treatment of common mental health disorders in adults," Cochrane Database Syst. Rev., vol. 2014, no. 6, 2014.

[3] M. Diouf et al., "Could baseline health-related quality of life (QoL) predict overall survival in metastatic colorectal cancer? The results of the GERCOR OPTIMOX 1 study," Health Qual. Life Outcomes, vol. 12, no. 1, pp. 1-12, 2014.

[4] A. C. Porter et al., "Predictors and outcomes of health-related quality of life in adults with CKD," Clin. J. Am. Soc. Nephrol., vol. 11, no. 7, pp. 1154-1162, 2016.

[5] S. Liebman, N. C. Li, and E. Lacson, "Change in quality of life and one-year mortality risk in maintenance dialysis patients," Qual. Life Res., vol. 25, no. 9, pp. 2295-2306, 2016.

[6] J. Perl et al., "Association between changes in quality of life and mortality in hemodialysis patients: Results from the DOPPS," Nephrol. Dial. Transplant., vol. 32, no. 3, pp. 521527, 2017.

[7] Naghavi M, Wang H, Lozano R, "GBD 2013 Mortality and Causes of Death Collaborators. Global, regional, and national age-sex specific all-cause and cause-specific mortality for 240 causes of death, 1990-2013: a systematic analysis for the Global Burden of Disease Study 2013," Lancet, vol. 385, no. 9963, pp. 117-171, 2015.

[8] P. Indonesian et al., "Indonesian Renal Registry 2016," pp. 146, 2016.

[9] Riskesdas, Laporan Nasional RISKESDAS 2018. Jakarta: Kementrian Kesehatan RI, 2018.

[10] C. T. Chan et al., "Dialysis initiation, modality choice, access, and prescription: conclusions from a Kidney Disease: Improving Global Outcomes (KDIGO) Controversies Conference," Kidney Int., vol. 96, no. 1, pp. 37-47, 2019.

[11] C. M. Imelda, Fitri; Susalit, Endang; Marbun, M Bonar; Rumende, "Clinical Features and Quality of Life in End Stage Renal Disease Gambaran Klinis dan Kualitas Hidup Pasien Penyakit Ginjal Tahap Akhir yang Menjalani Hemodialisis Dua Kali Dibandingkan Tiga Kali Seminggu," vol. 4, no. 3, pp. 128136, 2017
[12] sri atun Wahyuningsih, "Pengaruh Terapi Supotif Terhadap Kemapuan Keluarga Merawat Klien Gagal Ginjal Kronik Yang Menjalani Hemodialisa Di Rumah Sakit Pelni Jakarta,” p. 83, 2014.

[13] R. Damayanti and T. Hernawaty, "Influence of family supportive therapy on family skills about clients of survival disorders in kecamatan bogor timur," vol. 01 , no. 1, pp. 22-32, 2014.

[14] M. W. Wachterman, S. M. Hailpern, N. L. Keating, M. K. Tamura, and A. M. O'Hare, "Association between hospice length of stay, health care utilization, and medicare costs at the end of life among patients who received maintenance hemodialysis," JAMA Intern. Med., vol. 178, no. 6, pp. $792-$ 799, 2018.

[15] T. Luckett et al., "Advance care planning for adults with CKD: A systematic integrative review," Am. J. Kidney Dis., vol. 63, no. 5, pp. 761-770, 2014.

[16] B. Brady, L. Redahan, C. L. Donohoe, G. J. Mellotte, C. Wall, and S. Higgins, "Renal patients at end of life: A 5-year retrospective review," Prog. Palliat. Care, vol. 25, no. 5, pp. 224-229, 2017.

[17] R. J. Schmidt and A. H. Moss, "Dying on dialysis: The case for a dignified withdrawal," Clin. J. Am. Soc. Nephrol., vol. 9, no. 1, pp. 174-180, 2014.

[18] D. S. Mulia, E. Mulyani, and G. S. Pratomo, "Quality of Life of Chronic Kidney Disease Patients on Hemodialysis at Dr. Doris Sylvanus Hospital Palangka Raya," Borneo J. Pharm., vol. 1, no. 1, pp. 19-21, 2018.

[19] W. H. Organization, "Management of substance abuse: WHO Quality of Life-BREF (WHOQOL-BREF)," 2016.

[20] H. Jafari, A. Ebrahimi, A. Aghaei, and A. Khatony, "The relationship between care burden and quality of life in caregivers of hemodialysis patients," BMC Nephrol., vol. 19, no. 1, p. $321,2018$.

[21] L. Rabiei, A. A. Eslami, H. A. Abedi, R. Masoudi, and G. R. Sharifirad, "Caring in an atmosphere of uncertainty: perspectives and experiences of caregivers of peoples undergoing haemodialysis in Iran," Scand. J. Caring Sci., vol. 30, no. 3, pp. 594-601, 2016.

[22] E. L. Gilbertson, R. Krishnasamy, C. Foote, A. L. Kennard, M. J. Jardine, and N. A. Gray, "Burden of Care and Quality of Life Among Caregivers for Adults Receiving Maintenance Dialysis: A Systematic Review," Am. J. Kidney Dis., vol. 73, no. 3, pp. 332-343, 2019.

[23] V. L. Hoang, T. Green, and A. Bonner, "Informal caregivers' experiences of caring for people receiving dialysis: A mixedmethods systematic review," J. Ren. Care, vol. 44, no. 2, pp. 82-95, 2018.

[24] N. DePasquale, A. Cabacungan, P. L. Ephraim, L. Lewis-Boyér, N. R. Powe, and L. E. Boulware, "Family Members" Experiences With Dialysis and Kidney Transplantation," Kidney Med., vol. 1, no. 4, pp. 171-179, 2019.

[25] L. M. Tejada-Tayabas, K. L. Partida-Ponce, and L. E. Hernández-Ibarra, "Coordinated hospital-home care for kidney patients on hemodialysis from the perspective of nursing personnel," Rev. Lat. Am. Enfermagem, vol. 23, no. 2, pp. 225233, 2015.

[26] et all Ferrell, Betty R, Kravitz, Kate, "Family Caregivers," Clin. J. Oncol. Nurs., vol. 22, no. 3, pp. 286-294, 2018.

[27] P. F. Wiliyanarti and A. Muhith, "Life Experience of Chronic Kidney Diseases Undergoing Hemodialysis Therapy," NurseLine J., vol. 4, no. 1, p. 54, 2019. 